Prepared in cooperation with U.S. Fish and Wildlife Service

Monitoring Annual Trends in the Abundance of Eelgrass (Zostera marina) at Izembek National Wildlife Refuge in 2018

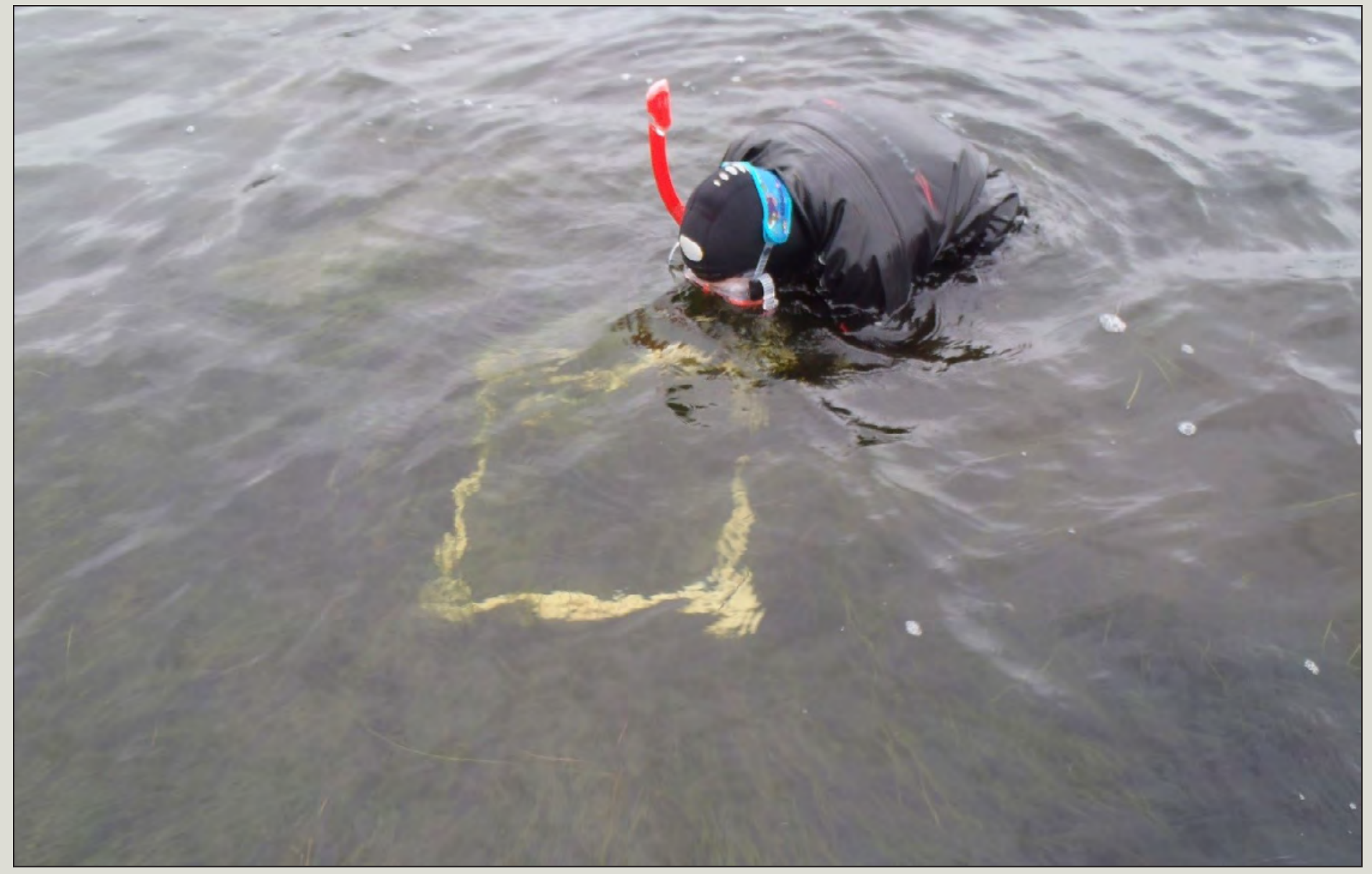

Open-File Report 2019-1042 
Cover: U.S. Fish and Wildlife Service personnel surveying eelgrass (Zostera marina) in Izembek Lagoon, Alaska, 2015. Photograph by David Ward, U.S. Geological Survey (public domain). 


\section{Monitoring Annual Trends in Abundance of Eelgrass (Zostera marina) at lzembek National Wildlife Refuge, Alaska, 2018}

By David H. Ward and Courtney L. Amundson

Prepared in cooperation with the U.S. Fish and Wildlife Service

Open-File Report 2019-1042 


\section{U.S. Department of the Interior \\ DAVID BERNHARDT, Secretary}

\section{U.S. Geological Survey James F. Reilly II, Director}

U.S. Geological Survey, Reston, Virginia: 2019

For more information on the USGS-the Federal source for science about the Earth, its natural and living resources, natural hazards, and the environment-visit https://www.usgs.gov/ or call 1-888-ASK-USGS (1-888-275-8747).

For an overview of USGS information products, including maps, imagery, and publications, visit https:/store.usgs.gov.

Any use of trade, firm, or product names is for descriptive purposes only and does not imply endorsement by the U.S. Government.

Although this information product, for the most part, is in the public domain, it also may contain copyrighted materials as noted in the text. Permission to reproduce copyrighted items must be secured from the copyright owner.

Suggested citation:

Ward, D.H., and Amundson, C.L., 2019, Monitoring annual trends in abundance of eelgrass (Zostera marina) at Izembek National Wildlife Refuge, Alaska, 2018: U.S. Geological Survey Open-File Report 2019-1042, 8 p., https://doi.org/10.3133/ofr20191042.

ISSN 2331-1258 (online) 


\section{Contents}

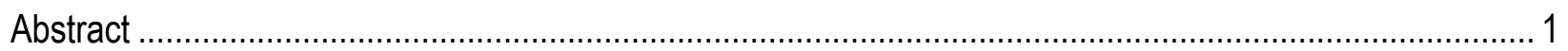

Introduction

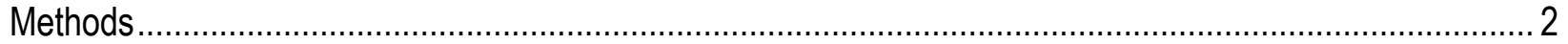

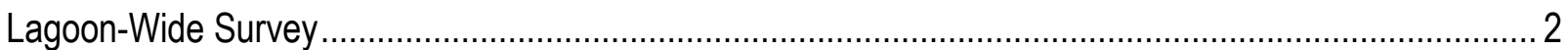

Site-Specific Eelgrass Survey at Grant Point ................................................................................. 4

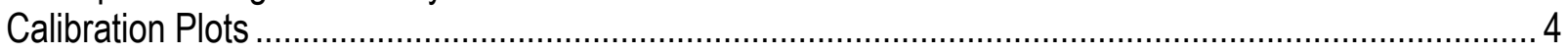

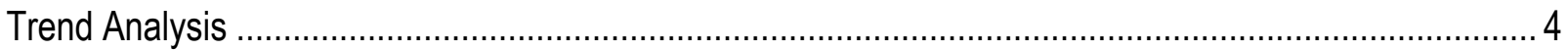

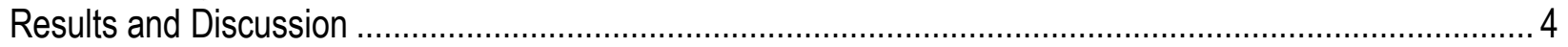

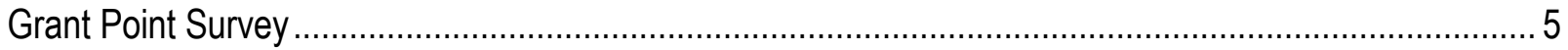

Trends in Eelgrass Abundance …………………………………………………………..

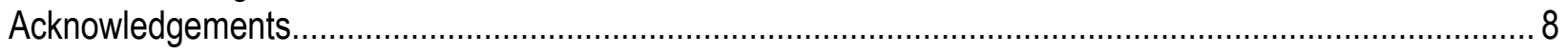

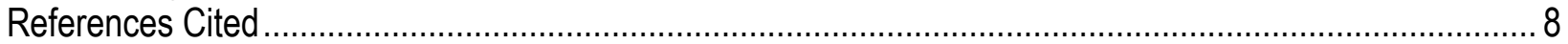

\section{Figures}

Figure 1. Satellite image with overlay showing distribution of sampling points used to monitor trends in the abundance of eelgrass (Zostera marina) in Izembek Lagoon, Izembek National Wildlife Refuge, Alaska, $2018(A)$ and all years ( $B ; 9$ years: 2007-11 and 2015-18) of the lagoon-wide point surveys.

Figure 2. Graphs showing mean shoot length and width of eelgrass sampled along two transects in Izembek Lagoon, Alaska, during April-May and July-August at the Old Boat Launch.

Figure 3. Graphs showing annual deviation in mean air temperature over 12 years (2007-18) during winter $(A)$ and growing season $(B)$ as recorded at the Cold Bay Airport, Alaska. Cold Bay airport is located about $12 \mathrm{~km}$ south of Izembek Lagoon.

Figure 4. Graph showing predicted aboveground biomass of eelgrass at Izembek Lagoon, Alaska, based on the lagoon-wide (points and 95 percent confidence interval bars) and Old Boat Launch (OBL) surveys during the peak of the growing season. 


\section{Conversion Factors}

U.S. customary units to International System of Units

\begin{tabular}{|c|c|c|}
\hline Multiply & By & To obtain \\
\hline \multicolumn{3}{|c|}{ Length } \\
\hline foot (ft) & 0.3048 & meter $(\mathrm{m})$ \\
\hline mile (mi) & 1.609 & kilometer $(\mathrm{km})$ \\
\hline \multicolumn{3}{|c|}{ Area } \\
\hline square mile $\left(\mathrm{mi}^{2}\right)$ & 2.590 & square kilometer $\left(\mathrm{km}^{2}\right)$ \\
\hline \multicolumn{3}{|c|}{ Flow rate } \\
\hline cubic foot per second $\left(\mathrm{ft}^{3} / \mathrm{s}\right)$ & 0.02832 & cubic meter per second $\left(\mathrm{m}^{3} / \mathrm{s}\right)$ \\
\hline \multicolumn{3}{|l|}{ International System of Units to U.S. customary units } \\
\hline Multiply & By & To obtain \\
\hline \multicolumn{3}{|c|}{ Length } \\
\hline meter $(\mathrm{m})$ & 3.281 & foot $(\mathrm{ft})$ \\
\hline meter $(\mathrm{m})$ & 1.094 & yard $(y d)$ \\
\hline kilometer $(\mathrm{km})$ & 0.6214 & mile (mi) \\
\hline kilometer $(\mathrm{km})$ & 0.5400 & mile, nautical (nmi) \\
\hline \multicolumn{3}{|c|}{ Area } \\
\hline square kilometer $\left(\mathrm{km}^{2}\right)$ & 0.3861 & square mile $\left(\mathrm{mi}^{2}\right)$ \\
\hline \multicolumn{3}{|c|}{ Flow rate } \\
\hline meter per year $(\mathrm{m} / \mathrm{yr})$ & 3.281 & foot per year (ft/yr) \\
\hline
\end{tabular}

Temperature in degrees Celsius $\left({ }^{\circ} \mathrm{C}\right)$ may be converted to degrees Fahrenheit $\left({ }^{\circ} \mathrm{F}\right)$ as follows:

${ }^{\circ} \mathrm{F}=\left(1.8 \times{ }^{\circ} \mathrm{C}\right)+32$ 


\title{
Monitoring Annual Trends in Abundance of Eelgrass (Zostera marina) at Izembek National Wildlife Refuge, Alaska, 2018
}

\author{
By David H. Ward and Courtney L. Amundson
}

\begin{abstract}
A lagoon-wide, point-sampling survey of eelgrass (Zostera marina) abundance was conducted in Izembek Lagoon, Alaska, August 7-16, 2018, the ninth year of annual surveys (2007-11, 2015-18). Mean predicted aboveground biomass of eelgrass across 116 sampled points was 238 grams per square meter $\left(\mathrm{g} \mathrm{m}^{-2}\right)$ (95 percent confidence interval: $203-278 \mathrm{~g} \mathrm{~m}^{-2}$ ) in 2018, an increase of 240 percent from the previous year's low estimate of $97 \mathrm{~g} \mathrm{~m}^{-2}(95$ percent confidence interval: $78-120 \mathrm{~g} \mathrm{~m}^{-2}$ ). The increase marked the third year since 2015 where eelgrass biomass was above the long-term mean $\left(158 \mathrm{~g} \mathrm{~m}^{-2}\right)$. Eelgrass biomass was stable over the 9 years of this survey. A separate (transect) survey for eelgrass abundance at Grant Point-Old Boat Launch showed annual trends in eelgrass biomass similar to the lagoon-wide survey, but over a slightly longer time (2007-18). The estimates of above-average eelgrass biomass in Izembek Lagoon were likely influenced by relatively warm air temperatures and little or no ice in winter (air temperatures 2.7 degrees Celsius greater than the 12-year mean) and average (cool) air temperatures during the growing season (April-August) in 2018.
\end{abstract}

\section{Introduction}

Eelgrass (Zostera marina) is the predominant macrophyte of protected embayments of southwestern Alaska, providing a wide range of ecosystem services to the coastal marine environment. Along the coast of the Izembek National Wildlife Refuge (INWR) in southwestern Alaska (fig. 1), eelgrass forms extensive meadows and some of the largest eelgrass meadows in the world (Ward and others, 1997; Hogrefe and others, 2014). These seagrass meadows support a rich diversity of marine organisms, virtually the entire Pacific flyway population of black brant (Branta bernicla nigricans), and significant numbers of emperor geese (Anser canagicus), cackling geese (Branta hutchinsii), dunlin (Calidris alpina), rock sandpipers (Calidris ptilocnemis), and Steller's eiders (Polysticta stelleri; King and Dau, 1981; Petersen and others, 1994; Fredrickson, 2001; Lewis and others, 2013).

The U.S. Fish and Wildlife Service and the Alaska Department of Fish Game, through the Izembek State Game Refuge, are stewards of the 34,200 hectares of aquatic lands in Izembek Lagoon (Alaska Department of Fish and Game, 2010). As part of this stewardship, INWR initiated a long-term monitoring program to assess the health and trends in the eelgrass population in Izembek Lagoon. A key component of this monitoring program is a lagoon-wide, point-sampling survey, which was initially developed and tested between 2007 and 2011. The primary objective of the lagoon-wide survey was to provide an annual estimate of above-ground 
biomass of eelgrass in Izembek Lagoon. This information may have important implications for management of the Pacific black brant population because eelgrass abundance in the lagoon is positively associated with the number of overwintering $(r=0.631)$ brant at INWR. Here, we present preliminary results on eelgrass abundance in Izembek Lagoon in 2018.

\section{Methods}

\section{Lagoon-Wide Survey}

To estimate eelgrass abundance in Izembek Lagoon in the study's early years (2007-09), we distributed sample points systematically across the entire lagoon. Later, we used a stratified random design (2010-11, 2015-18). The stratification was based on a July 2006 Landsat image of the distribution of eelgrass and non-vegetated (channels and mud/sand flats) areas in the lagoon (Hogrefe and others, 2014). Since the inception of the lagoon-wide survey in 2007, we have sampled 74-282 points per year. In 2018, we sampled 116 points (fig. 1).

Sample points were located by boat using a Global Positioning System (GPS) unit and sampled by snorkeling in dry suits during high tide. At each point, we measured water temperature, salinity, and depth, estimated cover of eelgrass and seaweeds, and determined the presence or absence of sessile invertebrates: mussels (Mytilus edulis), sponges, sea stars (Pisaster/Evasterias spp.), gastropods, Caprellid shrimp, and Telmessus crabs within four, 0.25 square meter $\left(\mathrm{m}^{2}\right)$ quadrats. The quadrats were positioned 1-4 meters $(\mathrm{m})$ from the GPS point in the four cardinal directions, thereby defining a sampling area of less than $50 \mathrm{~m}^{2}$ centered on the GPS point. Cover was defined as the part of the quadrat area obscured by eelgrass or seaweeds while viewed from above. Eelgrass was assessed to an approximate depth of $2.5 \mathrm{~m}$ below MLLW (mean lower low water), the approximate maximum depth of eelgrass in Izembek Lagoon (Ward and others, 1997). If eelgrass was present in a quadrat, 10 representative vegetative shoots were collected and measured for shoot length (meristem to tip of longest leaf) and width. If seaweeds were present, we estimated percent cover of all seaweed species combined and identified the most abundant species in the quadrat. 

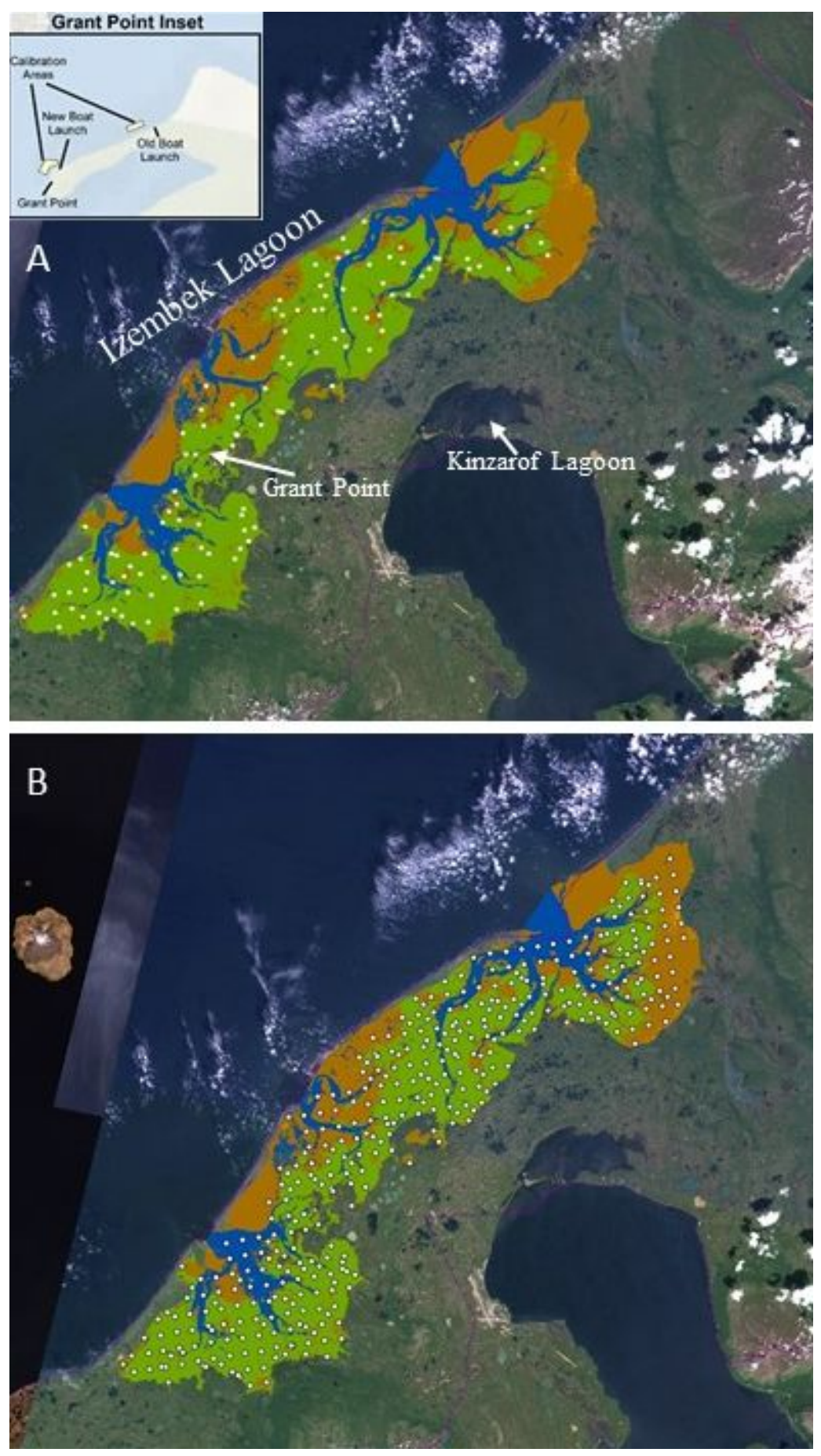

Figure 1. Satellite image with overlay showing distribution of sampling points used to monitor trends in the abundance of eelgrass (Zostera marina) in Izembek Lagoon, Izembek National Wildlife Refuge, Alaska, $2018(A)$ and all years ( $B ; 9$ years: 2007-11 and 2015-18) of the lagoon-wide point surveys. Green, eelgrass; brown, non-vegetative; blue, water. 


\section{Site-Specific Eelgrass Survey at Grant Point}

Supplemental to the lagoon-wide survey, we sampled seasonal changes in eelgrass cover, shoot length and width of eelgrass within randomly placed quadrats along two permanently established 100-m-long transects at Grant Point (that is, Old Boat Launch [OBL]; fig. 1A) in April and August. The transects were aligned parallel to the shoreline, with one situated in the high $(0.5 \mathrm{~m}$ mean lower low water [MLLW]) intertidal about $30 \mathrm{~m}$ from the proximal edge of the eelgrass meadow and the other placed in the lower (-0.2 MLLW) intertidal, about $65 \mathrm{~m}$ from the distal edge of the meadow. We estimated the percent cover of eelgrass and picked representative shoots within $100.25 \mathrm{~m}^{2}$ quadrats. Following collections (less than 2 days), 10 vegetative shoots were measured for length (meristem to tip of longest leaf) and width.

\section{Calibration Plots}

To convert percent cover estimates to above-ground biomass of eelgrass, we harvested shoots from 15 to 30 quadrats taken at Grant Point (that is, New Boat Launch [NBL] and OBL; fig. 1 inset). We estimated percent cover and collected all eelgrass shoots within the quadrat, removed dead leaves and belowground parts of the plant, and selected 10 representative shoots that were later measured for shoot length (meristem to tip of longest leaf) and shoot width. We then dried entire samples to constant mass at 50 degrees Celsius and weighed $(\mathrm{g})$ them to determine biomass per quadrat, which was scaled to $\mathrm{g}^{2}$. Calibration points represented the lagoon-wide range of sampling date, percent eelgrass cover and water depth.

\section{Trend Analysis}

Using calibration data, we estimated the functional relationship between eelgrass shoot length and percent cover and dried biomass per quadrat, using a log-Gamma generalized linear model. We then used this functional relationship to predict eelgrass biomass for lagoon-wide sampling. We assumed areas without eelgrass had biomass of zero without error and used a logithurdle log-Gamma model to separate zero and non-zero counts. Predicted biomass with error was used as the response variable in a generalized linear mixed model that included effects of substrate type (mud, sand, mud and sand mixture, cobble/rock), day of year of the survey, tideadjusted water depth, water temperature, and year on eelgrass biomass given it was present at a point. We implemented models using a Bayesian analysis framework in Jags (Plummer, 2003) run through the jagsUI package (Kellner, 2018) in R (R Core Team, 2018). We combined OBL transect and Grant Point calibration data collected 2007-18 and analyzed them separately using the same model structure. We then compared results to Lagoon-wide biomass estimates.

\section{Results and Discussion}

A total of 464 quadrat-points (116 points) were sampled in Izembek Lagoon on 6 days between August 6 and 172018 (fig. 1A). Strong winds prevented boat surveys on a third (4 days) of the 10-day sampling period. Eelgrass was present on 93 percent of the quadrat-points, and when present, occurred at a mean cover of $69 \pm 34$ percent [SD]. Mean length and width of eelgrass shoots were $42.2 \pm 47.8$ centimeters (range $=5-284$ centimeters) and $2.0 \pm 0.60$ millimeters (range $=1-5$ millimeters), respectively.

In contrast to eelgrass, seaweeds were present on slightly over half of the points (57 percent), and when present, occurred at relatively low mean cover of $17 \pm 18$ percent. Four genera of seaweeds were identified, and the predominant genera were 
Cladophora/Chaetomorpha (72 percent of quadrat-points) and Chordaria (25 percent of quadratpoints). The presence of the five macro-invertebrates was highly variable across quadrat-points. Gastropods (66 percent of quadrat-points) were the most commonly encountered invertebrate followed by Caprillid shrimp (24 percent), mussels (11 percent), sponges (10 percent), sea stars (3 percent), and Telmessus crabs ( 2 percent).

\section{Grant Point Survey}

The Grant Point survey occurred on April 20 and August 10. At the start of the growing season in April, overall mean shoot length and width of eelgrass were similar in 2018 and 2017 and were of average size compared to mean shoot lengths and widths in other years (fig. 2). By the peak of the growing season in August, the shoots tripled in length and were about 15 percent wider than in April. Mean shoot size in August increased in 2018 from the decade low in 2017 but was similar in mean shoot size to the rest of the study period (fig. 2).
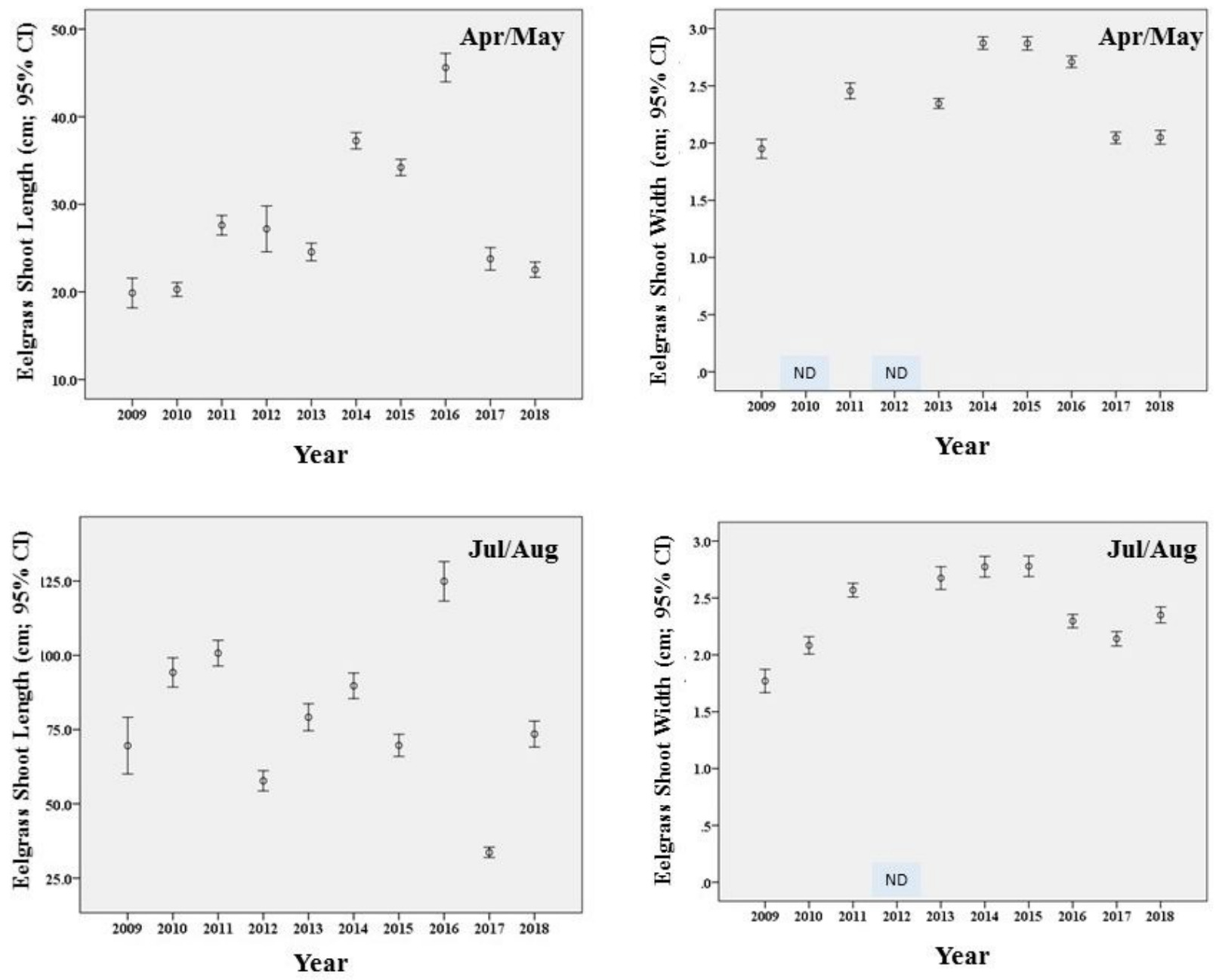

Figure 2. Graphs showing mean shoot length and width of eelgrass sampled along two transects in Izembek Lagoon, Alaska, during April-May and July-August at the Old Boat Launch. ND, no data collected. 
Winter (January-April) 2018 was the second warmest since 2007, the year lagoon-wide surveys were started in Izembek Lagoon, with mean air temperature 2.7 degrees Celsius greater than the 12-year mean (fig. $3 A$ ). This was also the sixth winter in the last eight with little or no ice in Izembek Lagoon. Mean air temperatures moderated during the growing season (MayAugust), with the mean air temperature during this season only slightly greater in 2018 than over the 12-year period (fig. 3B).
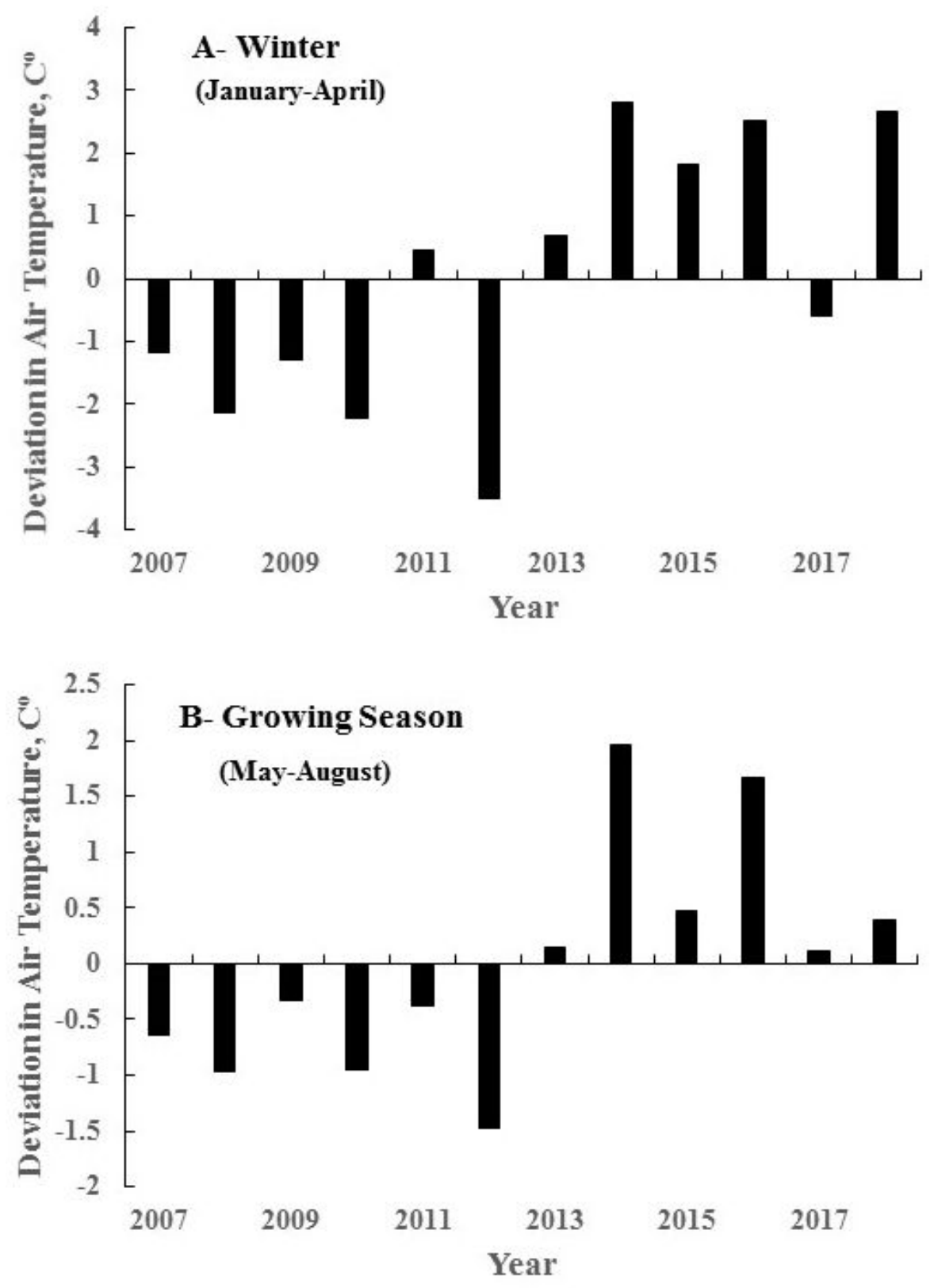

Figure 3. Graphs showing annual deviation in mean air temperature over 12 years (2007-18) during winter $(A)$ and growing season $(B)$ as recorded at the Cold Bay Airport, Alaska. Cold Bay airport is located about $12 \mathrm{~km}$ south of Izembek Lagoon. Data obtained online from National Centers for Environmental Information at National Oceanic and Atmospheric Adminstration, https://www.ncdc.noaa.gov/cdo-web/. 


\section{Trends in Eelgrass Abundance}

Mean predicted biomass of eelgrass based on the lagoon-wide survey was $238 \mathrm{~g} \mathrm{~m}^{-2}$ (95 percent confident interval [CI]: 203-278 $\mathrm{g} \mathrm{m}^{-2}$ ) in 2018, a $2.4 \times$ increase in eelgrass biomass from 2017 (fig. 4). Despite wide variability in mean annual estimates (minimum of $45 \mathrm{~g} \mathrm{~m}^{-2}$ in 2008 to maximum of $330 \mathrm{~g} \mathrm{~m}^{-2}$ in 2015), no trend was detected over the 9-year study period, 2007-11 and 2015-18 (fig. 4).

Mean predicted biomass of eelgrass in August at OBL was $190 \mathrm{~g} \mathrm{~m}^{-2}$ (95 percent CI: 113-307 $\mathrm{g} \mathrm{m}^{-2}$ ) in 2018 and was higher in the low intertidal zone (mean $=245 \mathrm{~g} \mathrm{~m}^{-2}, 95$ percent CI: $144-404 \mathrm{~g} \mathrm{~m}^{-2}$ ) than high intertidal zone (mean $=148 \mathrm{~g} \mathrm{~m}^{-2}, 95$ percent CI: $86-243 \mathrm{~g} \mathrm{~m}^{-2}$ ). Overall, mean predicted biomass across years was similar between the two surveys (that is, confidence intervals overlapped), except in 2007 and 2008, suggesting that OBL estimates can provide insight into trends for the entire lagoon between 2011 and 2015 (spanning data missing in the lagoon-wide survey).

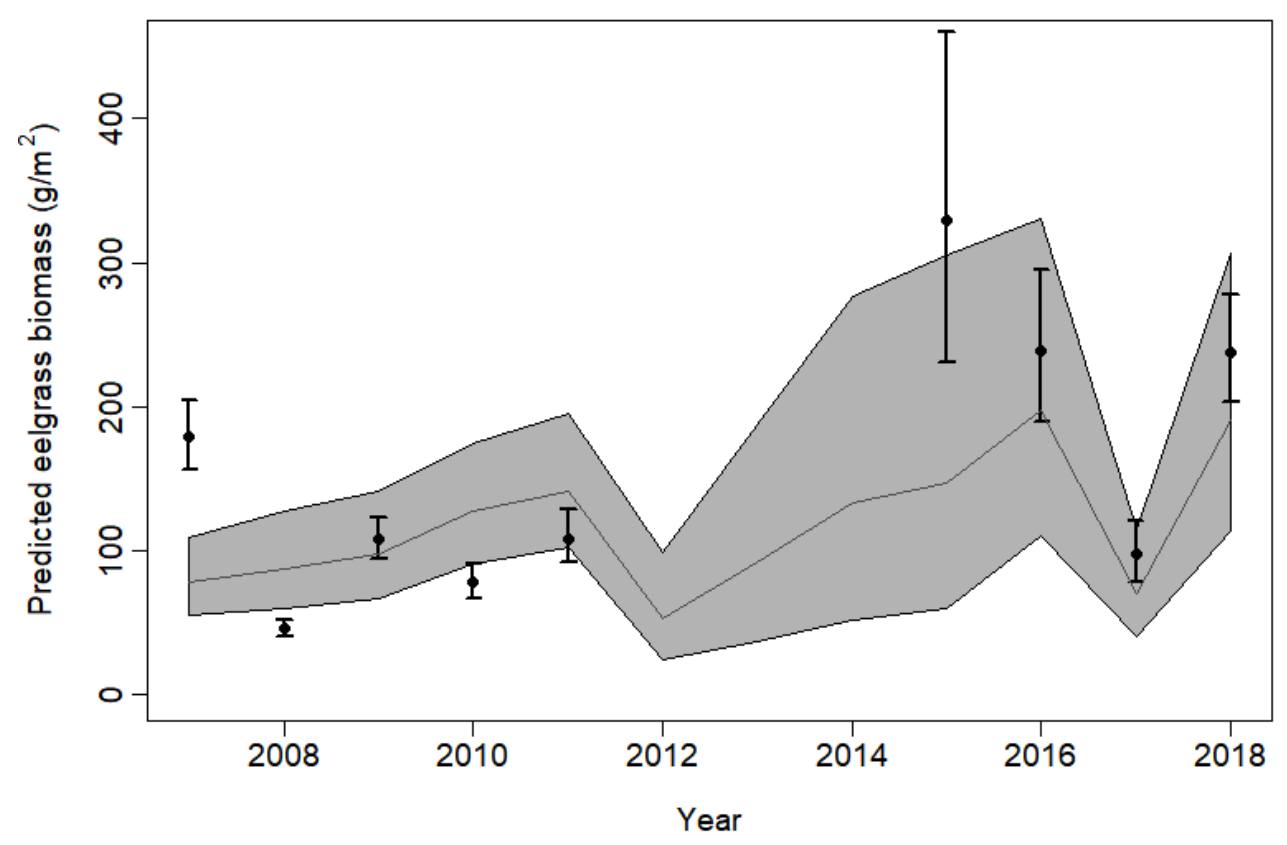

Figure 4. Graph showing predicted aboveground biomass of eelgrass at Izembek Lagoon, Alaska, based on the lagoon-wide (points and 95 percent confidence interval bars) and Old Boat Launch (OBL) surveys during the peak of the growing season. Predictions are for mean day of year, tide-adjusted water depth, water temperature and mud substrate type. Means, solid lines; shaded area, 95 percent confidence interval. 


\section{Acknowledgements}

We are especially thankful to Thomas Riecke (University of Nevada-Reno) and Damian Menning (U.S. Geological Survey, Alaska Science Center) for their assistance with the surveys in 2018. We also thank Greg Risdahl and Leticia Melendez (U.S. Fish and Wildlife Service [USFWS] Izembek National Wildlife Refuge) for their support of the eelgrass monitoring program. This study was funded by the USFWS under an Interagency Agreement to the U.S. Geological Survey (\#FF07RIZM00000-4500121400).

\section{References Cited}

Alaska Department of Fish and Game, 2010, Izembek State Game Refuge management plan: Alaska Department of Fish and Game.

Fredrickson, L.H., 2001, Steller's Eider (Polysticta stelleri), in Poole, A.F., ed., The birds of North America: Ithaca, New York, Cornell Lab of Ornithology, accessed February 9, 2019, at https://doi.org/10.2173/bna.571.

Hogrefe, K.R., Ward, D.H., Donnelly, T.F., and Dau, N., 2014, Establishing a baseline for regional scale monitoring of eelgrass (Zostera marina) habitat on the lower Alaska Peninsula: Remote Sensing, v. 6, p. 12447-12477.

Kellner, K.F., 2016, JagsUI-A wrapper around rjags to streamline JAGS analyses: The Comprehensive R Archive Network, https://cran.rproject.org/web/packages/jagsUI/index.html, accessed February 2016.

King, J.G., and Dau, C.P., 1981, Waterfowl and their habitats in the eastern Bering Sea, in Hood, D.W., and Calder, J.A., eds., The eastern Bering Sea shelf-Oceanography and Resources:

Office of Marine Pollution Assessment, National Oceanic and Atmospheric Administration, v. 2, p. 739-754.

Lewis, T.L., Ward, D.H., Sedinger, J.S., Reed, A., and Derksen, D.V., 2013, Brant (Branta bernicla), in Poole, A.F., ed., The birds of North America: Ithaca, New York, Cornell Lab of Ornithology, accessed February 9, 2019, at https://doi.org/10.2173/bna.337.

Petersen, M.R., Schmutz, J.A., and Rockwell, R.F., 1994, Emperor Goose (Chen canagica), in Poole, A.F., ed., The birds of North America: Ithaca, New York, Cornell Lab or Ornithology, accessed February 9, 2019, at https://doi.org/10.2173/bna.97.

Plummer, M., 2003, JAGS-A program for analysis of Bayesian graphical models using Gibbs sampling: Proceedings of the 3rd international workshop on distributed statistical computing, accessed February 9, 2019, at http://citeseer.ist.psu.edu/plummer03jags.html.

R Core Team, 2018, R-A language and environment for statistical computing: Vienna, Austria, R Foundation for Statistical Computing, accessed February 9, 2019, at https://www.Rproject.org/.

Ward, D.H., Markon, C.J., and Douglas, D.C., 1997, Distribution and stability of eelgrass beds at Izembek Lagoon, Alaska: Aquatic Botany, v. 58, p. 229-240. 
Publishing support provided by the U.S. Geological Survey Science Publishing Network, Tacoma Publishing Service Center

For more information concerning the research in this report, contact the Director, Alaska Science Center

U.S. Geological Survey

4210 University Drive

Anchorage, Alaska 99508

https://www.usgs.gov/centers/asc/ 
